\title{
副鼻腔結石様陰影を呈した2症例
}

一真菌症例, 遊離骨片例一

$$
\begin{aligned}
& \text { 州川明峰・山田一关 } \\
& \text { 川出 博彦・浅井否子 }
\end{aligned}
$$

\section{Two Cases of Roentgenologilly Stony Hard Shadows in Maxillary Sinuses}

\section{Meiho Nakayama, Kazumi Yamada, Hirohiko Kawade and Hideko Asai}

(Aichi Medical University)

Two cases of roentgenologilly stony hard shadows in maxillary sinuses are reported. One patient was a 52-year-old female whe complained of pharyngolaryngeal foreign-body sensation and post nasal rhinorrhea for 1 year. The other was a 28-yearold male who complained of nasal obstruction and rhinorrhea for 3 years with allergic nasal symptoms and strongly positive HD skin test. Both patients had a fungus ball and isolated bony tissue.

Key words: maxillary sinus, foreign-body, fungus ball, isolated bony tissue

\section{緒言}

卫鼻咽喉科領域において異物を検詩した場

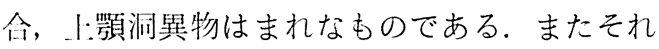
らのほとんどは外傷性によるものが多く, 結石 疼等のように，外傷によらないむのは，市村 ら の統計によると 100 例に渾たない。

われわれは愛知医科大学耳鼻咽喉科外来にお いて, 既往歴に顔面の外傷がなく, 单純レント ゲン写真において石様除影を認めた 4 例を経験 し，このうち手術に至った 3 例川の 2 例につき 郝售し，文献的考察を行った。

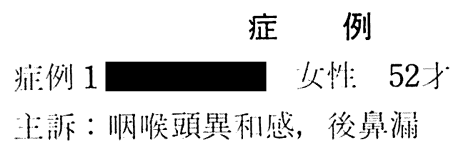

愛知医科大学耳鼻咽喉科学教室
既往歴：10年前より厌慢性中耳炎を指摘され る屯放犆.

現病歴：炤和59年頃より，後鼻漏が多く，抈 喉頭部に痰が掁りつく異和感があり, 近医にて 治療を続けたが不変.

妱和60年 7 月当院受診.

現症：不耳は艮好，左耳は良性第孔がある が, 鼓室内战謨は良好.

鼻腔内粘膜はやや把檿，右中鼻道に膿汁在涊 めた。鼻搹はほぼ快であった。

一般烅液, 尿検查成績等の検査成績は正: 常範 囲であった。

顔面単純写真，上頡洞断層写真にて存上顎润 内に結石様陰影, 及び粘膜肥厚像を示した（図 
1 ).

潭床経過：手術を锥如，昭和60年11月 6 日局 所麻酔で右上顎洞根治術に準じ，手術圭施行し た。上頭洞内は骨炎損はなく，犬歯窝骨面は正 常. 開空する屯洞粘膜は全周にわたり肥厚し， 脆弱であった。

右上䋶洞後壁中央よりやや上方に $12 \times 13 \mathrm{~mm}$ の

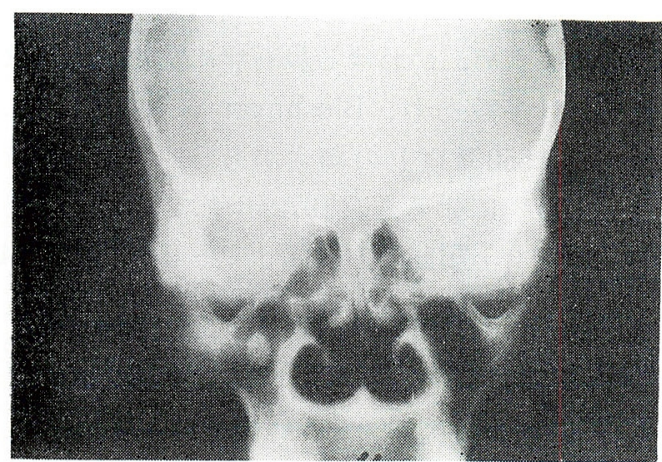

図 । 症例 1 の断層写真

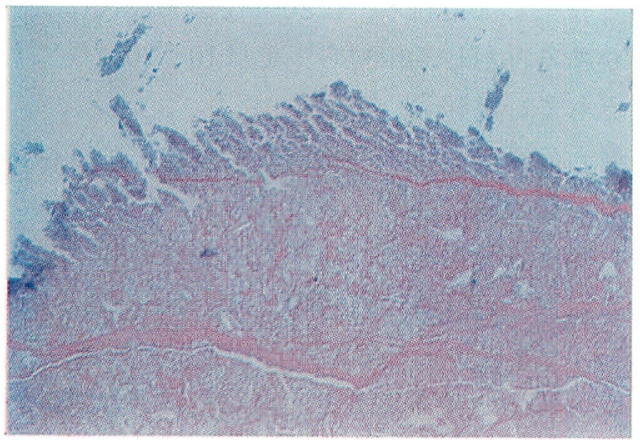

図 2 症例 1 の組織写真

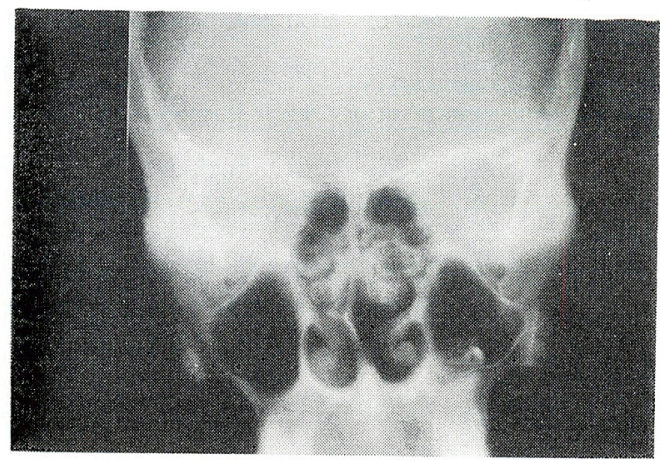

図 3 症例 2 の断首写真
球形の固体を摘出した。

病理組織において，赤色細顆粒状の真菌に囲 まれた赤色顆粒状の壊死組織老認め，右上䫟洞 内真菌症之判明した（図2）.

症例 2

男性 28 才

主訴：鼻閉，鼻漏

晒往歴：炤和57年 5 月, アレルギー性鼻炎に

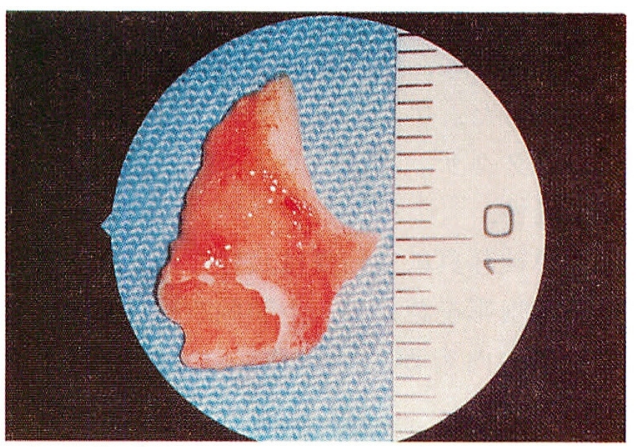

図 4 症例 2 で摘出された遊離骨片

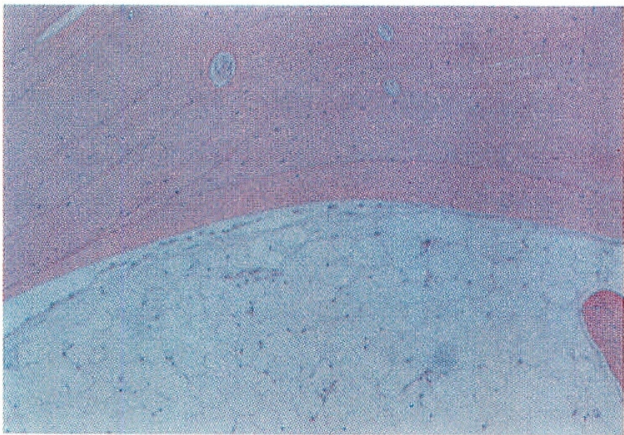

図 5 症例 2 の遊離骨片の組織写真

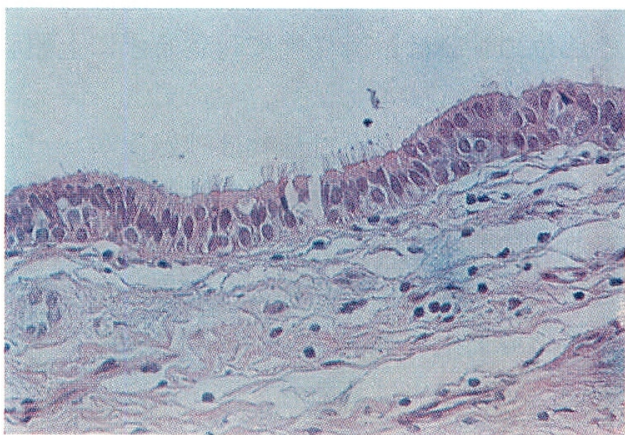

図 6 症例 2 の骨片に付着した粘膜の組織写真 
て，当院で治療を受けたが中断。当時，レント ゲン撮影せず.

現病歴：一時改善した鼻症状が悪化し，詔和 60年10月初より鼻閉，鼻漏を訴え，同年 10 月 18 日受診.

現症：両下鼻甲介の荅白, 肥厚及び右鼻腔へ 凸の鼻中隔弯曲が認められた。水様性鼻汁で膿 汁を認めず，その他の耳鼻咽喉科的所見は特に 異常を認めなかった。

一般血液, 尿, 生化学, 等の検査成績は正常 範囲であった。アレルゲンテストにてハウスダ スト, ブタクサ，アルテリナリア，パスパート 全てに陽性.

顔面単純写真にて粘膜は良好だが，左上顎洞 に結石様陰影を認めた。 上顎洞断層写真にて結

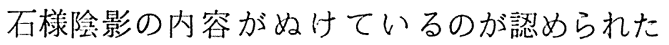
(図 3 ).

䍀床経過：患者の希望により，鼻処蠳，ネブ ライザー, 内服，ヒスタグロビンによる皮下注: 射, 等による保存的療法を続け, 炤和 61 年 4 月 9 日に鼻中隔弯曲矯正術, 下鼻甲介切除術及び 左上顎洞試験的開放術が施行された. 左上顎洞 試験的開放術に拈いて，犬䒠窩骨面は良好，上 顎洞内粘膜良好，骨火損がなく上顎洞底から13 $\times 10 \mathrm{~mm}$ の骨様物を摘出した。 上顎洞底は平坦で 火損がなく，雷根部との連絡はなかった，骨椂 物は一見蒾牙の様にみえ, 歯根部にあたる所は 上面に向き，歯冠部にあたるところは，円形の 陷凹があり，内部に上顎洞内粘膜之同様の粘膜 で充淽されていた。骨様物を除去する際は, 癒 着屯なく簡単に除去でき，その際，歯冠部にあ たる部位の粘膜は，骨㥞物に付着せずに上顎洞 内に残存した（図4）.

病理組織において，骨様物は外層部がハバー ス層板よりなる骨組織で, 内部は脂肪組織で允 茀されていた（図５）。骨様物を除去する際， 歯冠部にあたる部位に存在したと思われた粘膜 は, 多列線毛上皮よりなる小のう胞であった (図 6 ). 病理結果は遊離骨片であった。

\section{考按}

耳鼻咽喉科領域において，上顎洞内に異物を 認めるのはまれなケースである．またその多く は外傷性, 医原性によるものである. 中山ら²) によると，1963年から1982年間の 20 年間の上蕷 洞異物は 100 例前後であり，その30例は外傷性 によるもので，69例は医原性によるものであっ た。外傷性や医原性によらず，鼻症状を主訴之 した患者, レントゲン撮影洔偶然に発見された 患者等を含め，いわゆる鼻石症に関する報告は 欧米では多数あり，Bleshman ら ${ }^{3)}$ にるとて れまでに550例以上の報告がある．また本邦で は犬山ら り，中で屯上顎洞のみ限局してみるとそれは 24 例であった。市村ら は上顎洞結石症を43例と 報告しているが，いずれにしてもまれなもので ある。

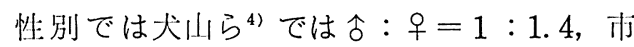
村ら ${ }^{1)}$ では令：早＝1：2 と女性にやや多く, 年榆分布では汿村ら ${ }^{1)} 20$ 歳代と50歳代にピー クがあると示し，田村ら ${ }^{5)}$ では10～20歳代にも っとも多いと報告している.

鼻石の成分について検討した場合，従来は燐 酸カルシウム, 燐酸マグネシウム, 炭酸カルシ ウムが主成分であるのに加え, 斎藤ら ${ }^{6)}$ はごく 微舅だが $\mathrm{Sr}, \mathrm{Cu}, \mathrm{F}, \mathrm{Rb}, \mathrm{Al}, \mathrm{Si}, \mathrm{As}, \mathrm{Cr}$, $\mathrm{B}, \mathrm{Li}$ ，等も含まれていると報告している.

成因について考えると，深江 ${ }^{7)}$ にれれば，鼻 汁のカルシウムや燐酸等の無機塩が析出しない のは, Mucin の強力な保護コロイドとして作 用している為であり，ての保護作用が消滅し， 同時に塩類析出に適当なpHを有していれば，塩 類が析出し，それが結石核として鼻石を形成す るとしている，文献的には，無核の結石を報告 しているあの屯あるが，乙の場合でも最初は核 となるべきものがあり，結石形成後にそれらが 吸収されたのではないかと考えられている。本 症例 1 では， 1 年以上の鼻症状の既往があり， この間に鼻汁，粘膜の壊死組織等が核となり結 石を形成し，それに真菌が付着したものと考え 
られる。

従来の結石症と鑑別しなければいけない疾患 に遊離骨片がある. Cunningham ら ${ }^{8)}$ や飯沼 ら が がそれを報告している。一般に慢性副鼻腔 炎にて第 2 期である線維型において骨新生や骨
片が生ずる骨病変がみられやすいとされてい る。荻野 ${ }^{10)}$ によれば，遊離骨片は陳旧性洞炎で 冒炎を経過した润腔に多く，その成立過程は図 7 の如く，いくつかの型に分けられるが，いず れにしてむ慢性副腔炎等の洞炎があり，それに
A. 遊離督片成岤過程

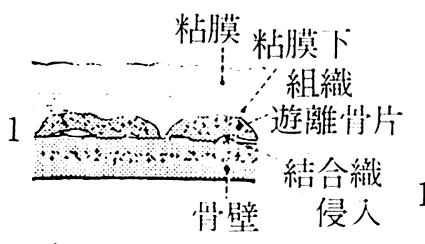

B. 三人遊離简片
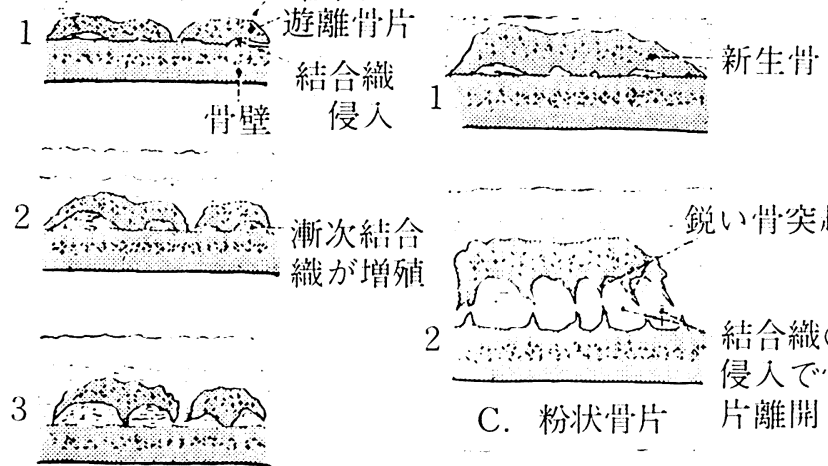

2

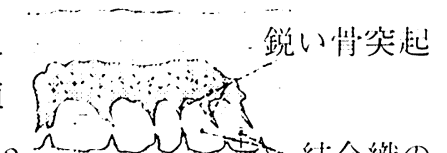

䄉の

C. 粉状骨片片離開
D. 下眼神経隆起部に 発生の遊離筩片

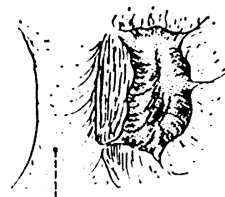

卜腿神経隆起

E. 造曰正遊離尙片 非成進行中

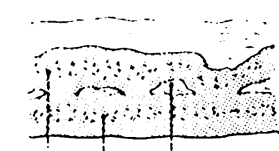

新牛胃学壁結合織

完全に遊離

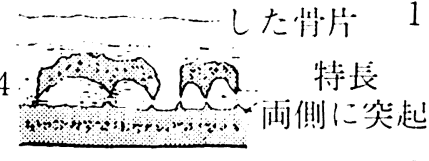

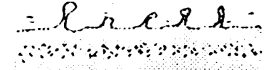

図 7 遊離骨片発生の機序（支献 ${ }^{102}$ より引用）

図 8 本学における上顎洞石様院影を示す症例

\begin{tabular}{|c|c|c|c|c|}
\hline \multirow[t]{5}{*}{ 患者氏名 } & 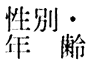 & 主 & 絴 & 過 \\
\hline & 우 51 & 右顔面の異和感 & $\begin{array}{l}\text { - S. 58. } 8.8 \text { 初 } \\
\text { - S. 58. } 9.14 \text { 手 } \\
\text { 6」の菊根摘出 }\end{array}$ & $\begin{array}{l}\text { 蘅 } \\
\text { 術 }\end{array}$ \\
\hline & 우 41 & 兴閉 & $\begin{array}{l}\text {. S. } 59.8 .29 \text { 初 } \\
\text { 手術せず }\end{array}$ & 䓂 \\
\hline & 우 52 & $\begin{array}{l}\text { 後 卑 漏 } \\
\text { 咽喉頭異和感 }\end{array}$ & $\begin{array}{c}\text { - S. } 60.7 .12 \text { 初 } \\
\text { - S. } 60.11 .6 \text { 手 } \\
\text { Fungus ball 摘 }\end{array}$ & $\begin{array}{l}\text { 膟 } \\
\text { 術 } \\
\text { 出 }\end{array}$ \\
\hline & 今 28 & 鼻閉，䙹漏 & $\begin{array}{l}\text { - S. } 57.5 .26 \text { 初 } \\
\text { - S. } 61.4 .9 \text { 手 } \\
\text { 骨塊摘出 }\end{array}$ & $\begin{array}{l}\text { 乵 } \\
\text { 術 }\end{array}$ \\
\hline
\end{tabular}


骨炎が合侀し，脱落した骨片と骨臂の間に結合 組織が侵入し，遊離骨片となるとされている。 本症例 2 でみられた歯牙状骨片は, 幅の広い八 バース層板よりなり，内部に骨梁及び脂肪織が みられる。また秚冠部にあたる部位の陷凹に洞 内粘膜之同㥞の線毛上皮がみられた。荻野説を 引用すれば，症例 2 は，手術に至るまでに 4 年 以上の改善增恵を繰り返す鼻汁, 鼻閉等の鼻症 状があり，乙の間に遊離骨片が形成され，骨壁 より離脱する際に壁内粘膜がその間に增生した 為，本症例でみられたような骨片となったと考 えられる.

この他，上顎润内結石症の鑑别として考える べき疾患は，市村ら ${ }^{1)}$ の文献を引用すると，

1.上顎润内逆生歯牙

2. 粘液垔腫

3. 歯原性腫瘍

4.上顎癌

5 ，骨肉腫

6. 線維性異形成

7. Gardner 症候群

8. 真菌塊

9. 遊離骨片

10. 石灰化䨑根郦胞

11. central cemento-ossifging fibroma

12. 造影剂の洞内貯留

等がある，近来，放射線の発達により上嶺洞 内異物をある程度磼酶する事ができるが，いず れにしても確定診断には摘出及び病理組織診が 必要である. 実際症例 2 において, 術前に逆性 歯牙, 絬石症等との鑑別には難であったケース であった。

\section{まとめ}

外伤性，定原性を伴わない上顎洞異物は珍し いものである，近年，本学において経験した上
䫈洞石様陰影を示した 4 症例中（図 8 )， 2 症 例につき検䚯を加え報告した。1 症例は結不 症， 1 症例は遊離骨片であった。 2 症例と屯 1 年以上の鼻漏等の鼻症状の既往があり，また確 定診断に至るまでには上顎润を開放し異物を摘 出し, 病理組織診を要した。

\section{参考文献}

1）市村恵一, 他：上顎洞内結石の 2 症例. 耳犊 47 : 121 127, 1975 .

2 ) 中山むつみ, 他：上罘洞内菌科材料異物の 1 症例 ならびに最近の上顎洞異物に関する文献的考察. 耳㽰 $55:$ 535 541， 1983.

3) Bleshman M, et al : Rhinolithiasis a report of 2 cases. Radiology 113:615 617, 1974.

4) 犬山征夫，他：高舲者にみられた鼼結石の 1 例と 本邦に扔ける統計的観察. 耳喉 $46: 47 \sim 50$, 1974.

5）田村浩地，他：䀘結石の一症例。広島大掭誌 11 : 217〜218, 1963.

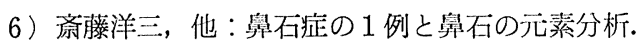
耳㡈 $47: 901 \sim 904,1975$.

7) 深江－：屚桃腺，鼻腔及び原腺の絬石並に其 の成因に就きて。十全会誌 $35: 2093 \sim 2119$, 1930.

8) Cunningham AT, et al : Rhinoliths ; the report of antral and three nasal stones. J Laryngol $60: 253 \sim 256,1945$.

9 ）飯沼寿孝, 他：上顎洞内の結石様塊. 耳筑 42 : 379 382, 1970.

10）荻野朝一：副鲟腔臨床応用解部図説. 306 312 頁, 医学畫院, 東京, 1967.

(別刷請求先：中山明峰

T480-11 愛知県愛知郡長久手町大字岩作字推又 21 愛知医科大学耳鼻咽喉科学教室 